\title{
ソーダガラスの曲げ応力-歪曲線への 電子線照射の影響*1
}

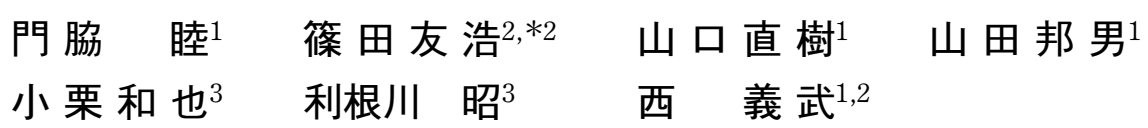

1東海大学大学院工学研究科金属材料工学専攻 2 東海大学工学部材料科学科

東海大学理学部物理学科

J. Japan Inst. Metals, Vol. 68, No. 3 (2004), pp. 202-205 (C) 2004 The Japan Institute of Metals

\section{Influences of Electron Beam Treatment on Bending Stress-Strain Curves of Soda Glass}

\author{
Atsushi Kadowaki ${ }^{1}$, Tomohiro Shinoda ${ }^{2, * 2}$, Naoki Yamaguchi ${ }^{1}$, Kunio Yamada ${ }^{1}$, \\ Kazuya Oguri ${ }^{3}$, Akira Tonegawa ${ }^{3}$ and Yoshitake Nishi ${ }^{1,2}$ \\ ${ }^{1}$ Graduate School of Materials Science, Tokai University, Hiratsuka 259-1292 \\ ${ }^{2}$ Department of Materials Science, Tokai University, Hiratsuka 259-1292 \\ ${ }^{3}$ Department of Physics, Tokai University, Hiratsuka 259-1292
}

Effects of electron beam (EB) irradiation on bending stress-strain curve were studied for soda glass. The stress-strain curves were measured by standard bending test. EB irradiation enhanced bending fracture stress and rigidity and then also enhanced the crack length of homogeneously fractured sample. The enhancements were mainly explained by the enlargement of bonding energy for silicon-oxygen atomic pair in atomic network structure of soda glass. The enlargement was probably induced by relaxation of the network structure, when EB irradiation generated the dangling bonds at the weaker bonded metal-oxygen atomic pairs in the network structure.

(Received November 7, 2003; Accepted January 27, 2004)

Keywords: soda glass, electron beam, bending fracture test, stress-strain curve, fracture stress, fracture strain, rigidity

\section{1. 緒言}

殺菌・防量 · 親水 · 表面硬化を付加する低エネルギー電子 線照射(EB)は，セラミックス材料表面の改質法として幅広 い応用が期待されている1-6). 一方, 電子線侵入深さと電子 の加速電圧 $(V: \mathrm{kV})$, さらに, 物質の密度 $\left(\rho: \mathrm{m}^{3}\right)$ との間に 関係があることが知られており, 式 (1)を用い電子線のガ ラスに対する侵入深さ (Depth : m) が算出できる7).

$$
\text { Depth }=0.0667 \times 10^{9} \times V^{5 / 3} / \rho
$$

特に, 密度 $2220 \mathrm{~kg} / \mathrm{m}^{3}$ のシリカを主成分とする無機ガラ スに EB 照射を行うと, 表面直下の約 $100 \mu \mathrm{m}$ 深さまで電子 線が侵入し, ネットワーク構造が乱れるだけでなく, 金属原 子と酸素原子の分子ペアーが分断され，不対電子が増加する ことを報告した1).これは, 凝固し熱処理したガラスのマク 口的な残留応力が緩和されることを示している．しかしなが ら，タイトなネットワーク構造を保持するこれらのガラスは 外部応力に対し緩和が起きにくく，これが脆性の主な原因々 なっている.このような構造をもつガラスに対して $\mathrm{EB}$ 照射

\footnotetext{
*1 2003 年 10 月 14 日日本金属学会秋期大会において発表

*2 東海大学学生 (Undergraduate Student, Tokai University)
}

を行うことにより，最も弱い結合が切れて不対電子が生じ， 自由体積が増大すると, 外部応力に対するネットワーク構造 の緩和が生じやすくなり, 延性が増大する可能性が高ま る ${ }^{1)}$.さらに, $\mathrm{Si}-\mathrm{O}$ 原子ペアーは緩和され原子間力が最大

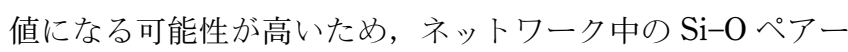
の結合力が高まり，変形抵抗が増大する可能性がある。すな

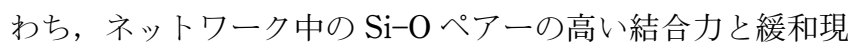
象は, EB 照射による大きな強勒化を引き起こす可能性が高 い1). ところで, 実用的観点からガラスビンやガラス板にお いて, 外力に対する変形抵抗や割れやすさの指標として曲げ 試験によって得られる応力一歪曲線から導出される曲げ破断 応力, 曲げ破断歪み, 剛性率などの結果は重要である.そこ で，本実験ではソーダガラスの応力-歪曲線に及ぼす EB 照 射の効果について検討を行った.

\section{2. 実 験 方 法}

\section{1 電子線 $(\mathrm{EB})$ 照射}

試料にはシリカを主成分とする松浪硝子工業侏製のマイク ロカバーガラス $(24 \mathrm{~mm} \times 24 \mathrm{~mm} \times 0.145 \pm 0.005 \mathrm{~mm})$ を用い た.この試料の組成分析による金属元素のモル比は $\mathrm{Si}$ : 
$\mathrm{Na}: \mathrm{K}: \mathrm{Al}: \mathrm{Mg}: \mathrm{An}=70: 13.2: 7.6: 5.9: 1.8: 1.0$ であ る. 組成分析にはアルバック・ファイ侏製 $\mathrm{X}$ 線光電子分光 分析装置 (ESCA; Quantum 2000) を用いた。分析条件は time/step $40 \mathrm{~ms}$, Probe 径 $100 \mu \mathrm{m}$, Pass. E. $23.5 \mathrm{eV}$, Step $0.1 \mathrm{eV}$, Sweeps 20, SPT $1 \mathrm{kv}-30 \mathrm{~s}$ で行った.

$\mathrm{EB}$ 照射には岩崎電気侏製エレクトロンカーテンプロセッ サー(PE : EC250/15/180L)を用いた ${ }^{1-6)}$ 。この装置は幅方 向にフィラメントを配置しているためカーテン状に電子線を 取り出すことができ, 広幅の処理, 高速処理に適している. また, 常温, 大気圧下での処理が可能であることが大きな特 徵である. $\mathrm{EB}$ 照射条件は照射電流 $4.6 \mathrm{~mA}$, 加速電圧 170 $\mathrm{kV}, \mathrm{EB}$ 照射処理雾囲気は酸素濃度 $30 \mathrm{ppm}$ 以下, 窒素雲囲 気 $(0.1 \mathrm{MPa}$ 圧力気流中：流速 $9.4 \mathrm{~L} / \mathrm{min})$ である. $\mathrm{EB}$ 照射 は試料を $0.30 \mathrm{~m}$ 角の試料フォルダの上に置き，これをコン ベア一速度 $10 \mathrm{~m} / \mathrm{min}$ でベルトコンベアにのせ均一に照射を 行った.この時の一回の照射時間を 0.23 秒とし, 照射線量 は照射回数により制御した。試料表面温度は $25 \mu \mathrm{m}$ のアル メル・クロメル熱電対で接触測定したところ, 照射直後 50 $\mathrm{K}$ 以上上昇することはなかった. 試料に対する $\mathrm{EB} の$ 照射面 積は均一である.なお, この条件で照射を行うと, 一回当た り $0.0432 \mathrm{MGy}$ の照射量となる. 照射量は以下の式で与えら れる6).

$$
\text { Dosage }(\mathrm{MGy})=0.094 \times(I / S) \times N
$$

式中の $I(\mathrm{~mA})$ は照射電流, $S(\mathrm{~m} / \mathrm{min})$ はコンベアー速度, $N(N=1,2,3 \cdots)$ は照射回数である. 照射線量の校正はナイ ロン線量計 (FAR WEST TECHNOLOGY, カリフォルニア 州)を用いた。

式 (1)の侵入深さの式で, 試料に対する電子線侵入深さ を求める場合, 電子線が電子線源から試料に到達するまで に，電子線通過に伴う電圧降下を考慮する必要がある．電子 線通過に伴う電圧降下を電子線侵入距離と $\mathrm{Ti}$ 薄板の厚さよ り算出し, さらに窒素ガス層についても式 (1)を用い, 同 様の計算を行い試料表面での算出を行った ${ }^{8)}$. 本装置の電子 線照射密は Ti 製(密度 : $4540 \mathrm{~kg} / \mathrm{m}^{3}$ ) であり, 厚さが $13 \mu \mathrm{m}$ の薄板を使用している. また照射空から試料間は大気圧の窒 素ガス (密度 : $1.13 \mathrm{~kg} / \mathrm{m}^{3}$ ) で満たされており, 距離は 45 $\mathrm{mm}$ である. 以上の結果と式 ( 1 ) から, 加速電圧が $170 \mathrm{kV}$ の場合, 試料表面での電圧は $112 \mathrm{kV}$ で算出された. 今回用 いたソーダガラスの密度 $\rho$ は $2430 \mathrm{~kg} / \mathrm{m}^{3}$ である.これらの 值から式 (1) で計算すると, ソーダガラスへの電子線侵入 深さは $71.8 \mu \mathrm{m}$ である.

なお, 温度上昇に伴う不対電子や自由体積の消滅を防ぐた めに，両面に交互に短時間で照射を行い，これを 1 サイク ルとした．このサイクル数を増やすことにより照射線量を積 算し, より大きい照射線量を得た.

\section{2 強度評価方法}

本研究では曲げ試験法を用いて, EB 照射処理の曲げ強度 への影響について検討した(JIS R 1601-1995). 試験片作製 の際の切断時に, ガラス切断面に生じる傷がある面に, 引張 応力がかかる様に曲げ試験を行った．傷の観察は試料断面の 光学顕微鏡観察を行った. 曲げ試験には 4 点曲げ試験法を

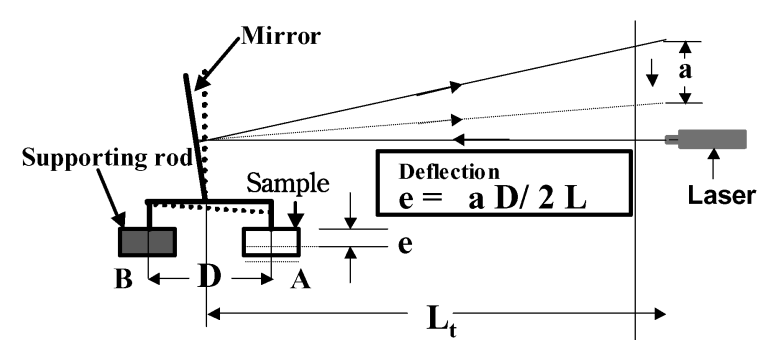

(a)

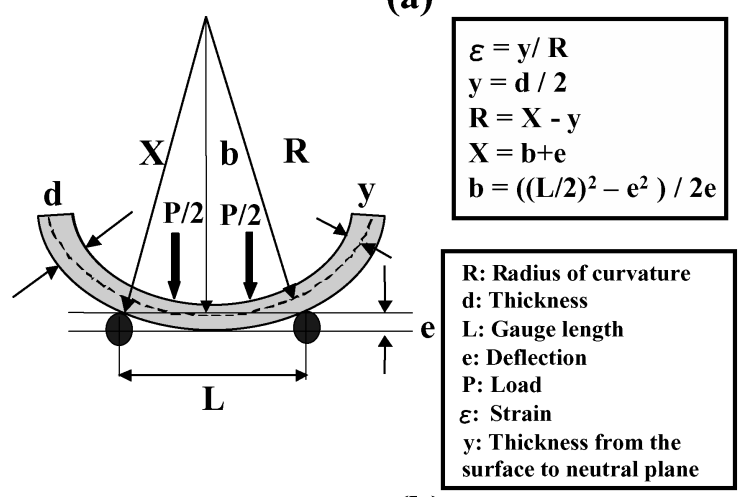

(b)

Fig. 1 Schematic diagram of Ewing optical strain measurement system (a) and bending test (b).

用い, Ewing の原理を用いて曲げ歪の測定を行った. Fig. 1 に歪算出の模式図を示す. 歪は試料のたわみの中点降下 $e$ を 光梃子法によって測定し, 中点降下 $e$ の值から曲率半径 $R$ を求める事により算出した. 曲げ歪の算出式を式 (3)に示 す.

$$
\varepsilon=e d /\left((L / 2)^{2}+e(e-d)\right)
$$

式中の $\varepsilon$ は歪, $e(\mathrm{~mm})$ は試料のたわみの中点降下值, $d(\mathrm{~mm})$ は試料厚さ, $L(\mathrm{~mm})$ は下部支点間距離である. また, Fig. 1 の $X(\mathrm{~mm})$ と $b(\mathrm{~mm})$ はそれぞれ曲率半径 $R(\mathrm{~mm})$ の中 心から下部支点までの距離と試料表面までの垂線の長さであ る.さらに, 以下の式 $(4)$ より, 曲げ応力を算出した.

$$
\sigma[\mathrm{MPa}]=3 P(L-l) / 2 w d^{2}
$$

式中の $\sigma(\mathrm{MPa})$ は曲げ応力, $P(\mathrm{~N})$ は負荷荷重, $L(\mathrm{~mm})$ は下 部支点間距離, $l(\mathrm{~mm})$ は下部支点距離, $w(\mathrm{~mm})$ は試料の幅 である。

なお, 実験の結果から照射線量毎の剛性率の算出と曲げ試 験後の破片からクラックの総延長距離を算出し割れのメカ二 ズムについての検討も行った.

\section{3 不対電子の評価方法 $1,6,9)$}

ガラスに対して EB 照射を行うと不対電子が生成されるこ とから, EB 照射による不対電子の評価を行うために日本電 子侏製電子スピン共鳴装置 (ESR; JES-FA200)を用いて測 定を行った. 測定条件はX-band(周波数： 9.4〜 9.5 GHz), $100 \mathrm{kHz}$ の磁場変調で室温において行った。測定は積算 EB 照射サイクルで 0, 5, 10, 15, 20, 25, 30 サイクルについて行 い，それぞれ不対電子の数を測定した。 


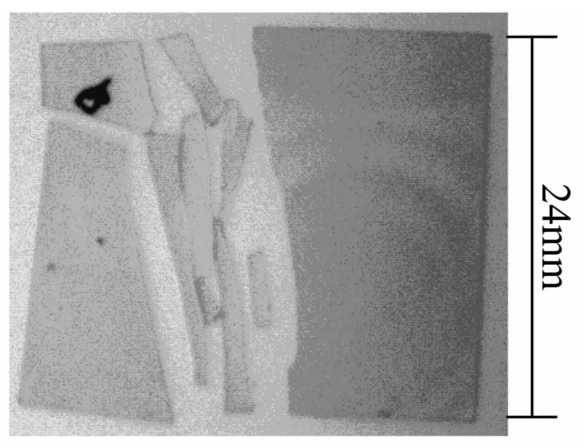

(a)

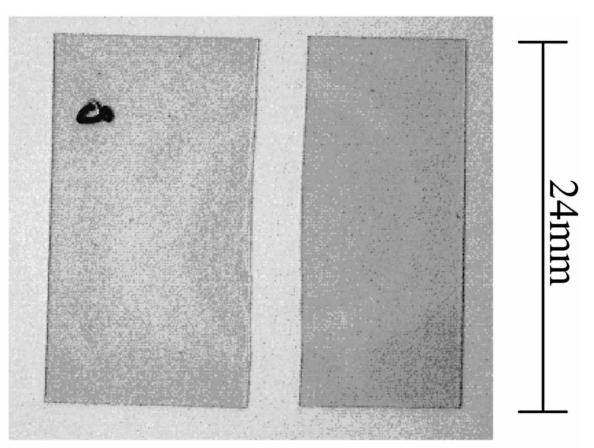

(b)

Fig. 2 Photograph of homogeneously (a) and heterogeneously (b) fractured soda glass.

\section{3. 結果と考察}

Fig. 2 に均質破壊と不均質破壊時の試料片の状態を示す. 不均質破壊は試験片の傷や不純物に応力が集中し, 破壊の起 点となり, 低い応力や微小歪で破壊が開始することが期待で きる. 一方，このような起点が存在しないと高い応力の負荷 により写真に見られる均質な破壊が見られることが期待でき る. そこで, 本研究では主に均質破壊に及ぼす電子線照射の 効果について検討した.

Fig. 3 に電子線 (EB) 照射し, 均質破壊したソーダガラス に関する曲げ試験で得られた応力一歪曲線を示す。この図よ り， $\mathrm{EB}$ 照射では曲げ破壊応力や応力一丕曲線の傾きである 剛性率が高まることが確認出来る.

Fig. 4 に EB 照射線量と剛性率の関係を示す. Figs. 3, 4 より, 0.4 MGy までは電子線照射したソーダガラスの剛性 率が未処理の試料に比べ約 $40 \%$ 高まることが確認できた.

Fig. 4 に EB 照射線量と曲げ破壊応力の関係も示す.ソーダ ガラスの曲げ破壊応力も電子線照射により約 $30 \%$ 上昇する ことを確認した。

ソーダガラスの曲げ破壊試験において, 破片の大きさが異 なる場合のあることが Fig. 2 で確認された.この結果, 不 均質破壊により, 低い応力や微小歪で破壊が開始され, 試験 片が 2 枚の大きな破片に破壊する. 一方, このような起点 が存在しない均質な材料は, 均一に変形し, 高い応力まで破 壞しない.さらに, 比較的均一に変形するので, 破壊の起点 が多くなる確率が高く, 試験片が細かく破壊する, すなわ ち, クラック長が長い破壊が見られる可能性が高い. そこで,

Fig. 5 に示すクラック長に及ぼす電子線照射の効果について 検討した. その結果, 点線で示す不均質破壊のクラック長は 变化しないが, 実線で示す均質破壊のクラック長(破壊面の 総延長距離) は 0.4 MGy までの電子線照射により長くなるこ とを確認した.

この図から曲げ破壊応力の増大が総クラック長さに対応す る傾向が見られた.すなわち, ソーダガラスの曲げ破壊試験 に掞いて, 破壊応力が大きいほど破片が細かくなる傾向がみ られた。

密度 $2220 \mathrm{~kg} / \mathrm{m}^{3}$ のシリカを主成分とする無機ガラスに

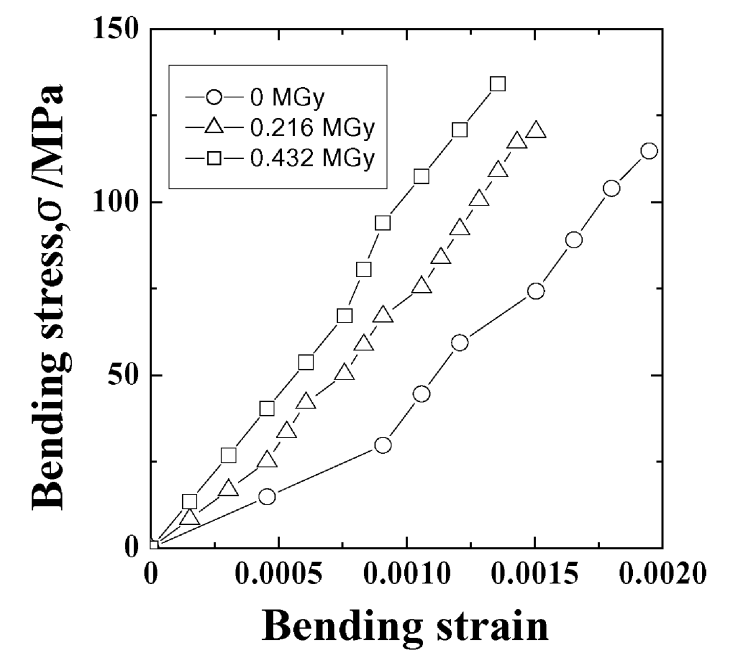

Fig. 3 Stress-strain curves of homogeneous fractured on bending test at different EB irradiation dosed.

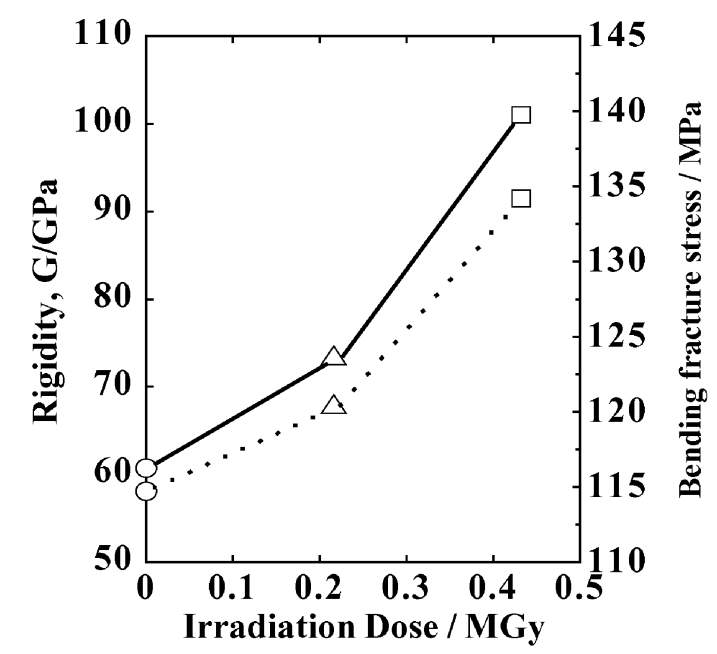

Fig. 4 Change in rigidity and bending fracture stress against EB irradiation dose.

$\mathrm{EB}$ 照射を行うと, 表面直下の約 $100 \mu \mathrm{m}$ 深さまで電子線が 侵入し, ネットワーク構造が乱れ, 弱い金属原子と酸素原子 の分子ペアーが分断され，不対電子が増加するはずである. そこで, ESR 測定により, 不対電子の存在を確認した ${ }^{9)}$. 


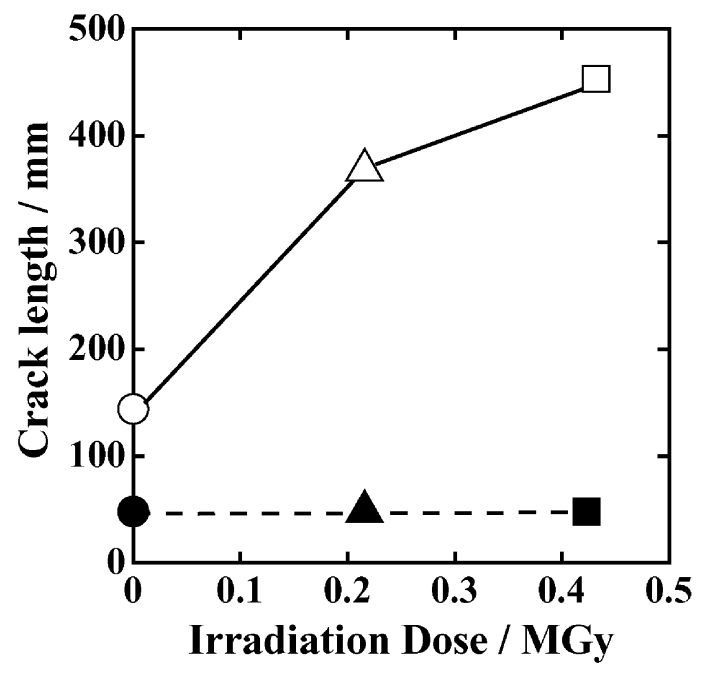

Fig. 5 Change in crack length in sample against EB irradiation dose. Solid and dotted lines were for homogeneous and heterogeneous fracture, respectively.

Fig. 6 に EB 照射線量と不対電子生成量の関係について示 す。この図より，EB 照射により不対電子が生成しているこ とを確認した。 高純度シリカガラスの E プライムセンター と比較し10)，この ESR シグナルは明らかに異なる形状であ る.このことからシリコン原子以外の金属元素で不対電子が 生成したものと仮定し, 以下の考察を行った.

タイトなネットワーク構造を保持するこれらのガラスは外 部応力に対し緩和しにくく，これが無機ガラスの脆性の主な 原因となっている.このような構造をもつガラスに対して EB 照射を行うと, 最も弱い結合が切れて不対電子が生じ, 自由体積が増大する. この状態の試料に外部応力を加えると, $\mathrm{Si}-\mathrm{O}$ 原子ペアーが基盤となるネットワーク構造の緩和が生 じやすくなる.さらに, 緩和された $\mathrm{Si}-\mathrm{O}$ 原子ペアーは原子 間力が最大值になる位置にある可能性が高いため, ネット ワーク中の $\mathrm{Si}-\mathrm{O} ヘ ゚ ア ー の$ 結合力が高まり, 変形抵抗が増大 し, 剛性率が高まると考察した。すなわち，EB照射した試 料の最も弱い結合の切断に伴う応力緩和機構が，ネットワー

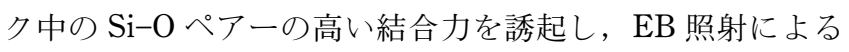
高い剛性率と大きな破壞応力を引き起こすと考察した.

\section{4. 結 言}

本研究では, ソーダガラスにおける曲げ応力一歪み曲線に おける電子線照射 (EB)の効果について検討を行った. 応力一

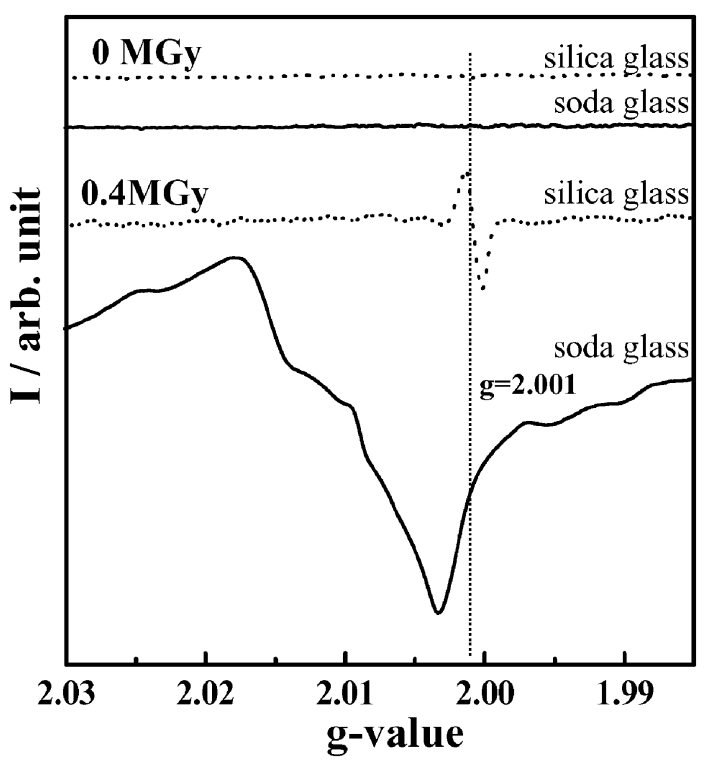

Fig. 6 ESR signals of soda and silica glasses at different EB irradiation dose.

歪み曲線は標準曲げ試験 (JIS R 1601-1995)によって測定し た．EB 照射によってソーダガラスの曲げ破断応力と剛性率 が改善された。この EB 照射による高い剛性率と大きな破壊 応力は EB 照射による最も弱い結合の切断に伴う応力緩和機

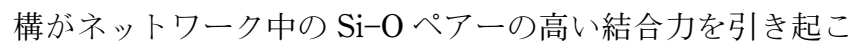
し， EB 照射による高い剛性率と大きな破壊応力を引き起こ すと考察した.

文献

1) Y. Nishi, A. Mizutani, K. Oguri and A. Tonegawa: Mater. Tech. $1(2002)$ 25-27.

2) Y. Nishi, H. Izumi, J. Kawano, K. Oguri, Y. Kawaguchi, M. Ogata, A. Tonegawa, K. Takayama, T. Kawai and M. Ochi: J. Mater. Sci. 32(1997) 3637-3639.

3) K. Oguri, K. Fujita, M. Takahashi, Y. Omori, A. Tonegawa, N. Honda, M. Ochi, K. Takayama and Y. Nishi: J. Mater. Res. 13 (1998) 3368-3371.

4) K. Oguri, N. Iwataka, A. Tonegawa and Y. Nishi: Proc. The 6th Jpn Inter. SAMPE Sympo., Oct. 26-29(1999) 1055-1058.

5) T. Ojima, N. Iwataka, K. Aoki, Y. Nishi, A. Tonegawa and Y. Hirose: J. Adv. Sci. 8(1996) 103-105.

6) Y. Nishi, T. Toriyama, K. Oguri, A. Tonegawa and K. Takayama: J. Mater. Res. 16(2001) 89-92.

7) A. Mizutani and Y. Nishi: Mater. Trans. 44 (2003) 1857-1860.

8) G. Wakalopulos: Radtech Report, July/August (1998) 10-15.

9) N. Yamaguchi, K. Oguri, A. Tonegawa and Y. Nishi: J. Japan Inst. Metals 68 (2004) 198-201. 